Relations industrielles

Industrial Relations

\title{
The Legality of Picketing
}

\section{Suzanne Handman et John Leopold}

Volume 34, numéro 1, 1979

URI : https://id.erudit.org/iderudit/028942ar

DOI : https://doi.org/10.7202/028942ar

Aller au sommaire du numéro

Éditeur(s)

Département des relations industrielles de l'Université Laval

ISSN

0034-379X (imprimé)

1703-8138 (numérique)

Découvrir la revue

Citer cet article

Handman, S. \& Leopold, J. (1979). The Legality of Picketing. Relations industrielles / Industrial Relations, 34(1), 158-182.

https://doi.org/10.7202/028942ar
Résumé de l'article

The authors attempt, by means of « jurisprudence » to determine the conditions and circumstances which render picketing legal or illegal. Within this context, picketing will be examined from the point of view of object, form and occasion. In addition, the sanction of picketing will be presented, followed by a critique of the subject.
Tous droits réservés (C Département des relations industrielles de l'Université Laval, 1979
Ce document est protégé par la loi sur le droit d'auteur. L’utilisation des services d'Érudit (y compris la reproduction) est assujettie à sa politique d'utilisation que vous pouvez consulter en ligne.

https://apropos.erudit.org/fr/usagers/politique-dutilisation/ 


\title{
The Legality of Picketing
}

\author{
Suzanne Handman \\ and \\ John Leopold
}

The authors attempt, by means of «jurisprudence» to determine the conditions and circumstances which render picketing legal or illegal. Within this context, picketing will be examined from the point of view of object, form and occasion. In addition, the sanction of picketing will be presented, followed by a critique of the subject.

Picketing constitutes one of the forms of pressure generally associated with labour disputes and particularly strikes. The term "picketing» is ancient. Originally, it was used in connection with military activities, describing a party of sentinels or an outlying post. ${ }^{1}$ The earliest use of the term in legal literature has been traced to the case of Regina $v$. Druitt ${ }^{2}$ in 1867 , but the actions which it encompasses have been known to the law for a much longer period. ${ }^{3}$ Since the term is not a legal one, its meaning must be derived from popular usage. The following passage from the Encyclopaedia of the Social Sciences, cited by Finkelman, provides an explanation of what picketing connotes: ${ }^{4}$

«The principal method employed to prevent strike breaking is that of picketing by strikers or their representatives at or near the entrance to the place of employment.»

Thus picketing consists of the presence of one or more persons with or without placards, generally at the premises of the employer during a labour conflict. This device is employed for any one or more of the following purposes: to inform those unaware of the fact that a strike is in progress; to persuade workers to join the strike; to discourage or prevent the public from doing business with the «struck» establishment, or to urge non-unionized workers to join the union.

* HANDMAN, Suzanne, Université de Montréal

LEOPOLD, John, Université de Montréal

1 Board of School Trustees of School District No. 61 v. Canadian Union of Public Employees, (1977) 71 D.L.P. (3d) 139.

2 (1867) 10 Cox C.C. 592.

3 Jacob FINKELMAN, «The Law of Picketing in Canada», (1931) 2 Toronto.

L.J. 67 at p. 67.

4 Ibid., p. 69. 
Although picketing is a relatively common and familiar occurence, its legal status poses a problem. There is no reference whatsoever to picketing in the Quebec Labour Code or in any other Quebec law. The Canadian Labour Code provides no solution since this code also does not mention the term.

At present, the only Canadian province which has any legislation dealing with the subject is British Columbia. The work «picket» appears in the Labour Code of British Columbia, 1974 c. 87, and is defined in S. 1 in the following manner:

«Picket or "picketing» means watching and besetting, or attending at or near an employer's place of business, operations or employment for the purpose of persuading or attempting to persuade anyone not to:

i) enter that employer's place of business, operations or employment; or

ii) deal in or handle the products of that employer; and

iii) do business with that employer, and any similar act at such place that has an equivalent purpose.»

This definition confines and limits picketing in terms of place, that is, at or near any employer's place of business; and in terms of purpose, that is, of persuading or attempting to persuade anyone not to enter that employer's place of business, operations, or employment.

With the exception of British Columbia, due to the absence of any other legislation on picketing, all other provinces must fall back on the Criminal Code, since it is the only law which deals with the activity without, however, specifically using the term.

\section{Article 381 of the Criminal Code states in part:}

1. «Everyone who, wrongfully and without lawful authority, for the purpose of compelling another person to abstain from doing anything that he has a lawful right to do, or to do anything that he has a lawful right to abstain from doing...

f) besets or watches the dwelling house or place where that person resides, works, carries on business or happens to be, or...

is guilty of an offence punishable on summary conviction.

2. A person who attends at or near or approaches a dwelling house or place for the purpose only of obtaining or communicating information does not watch or beset within the meaning of this section. »

Although the words "watches» and «besets» are not defined by this article, it has been recognized and accepted that they refer to the activity known as picketing. Thus, because of the exception established by paragraph 2 of article 381 , picketing an establishment for the purpose of obtaining or communicating information does not constitute an offence. 
The Criminal Code implicity defines and permits picketing. It does not, however, indicate to what extent this conduct is permissible. Neither the limits nor the effects are codified.

Picketing may serve various purposes. It may vary as to its form and take place during different occasions. For example, picketing may consist solely of a few persons quietly walking back and forth carrying placards stating their grievances. However, can picketers verbally assault others in their attemts to persuade them of their cause and can they go as far as resorting to physical violence? Just how much of the foregoing can a picket carry out?

The purpose of this paper is to analyse this problem. More specifically, the authors will attempt, by means of «jurisprudence» in Quebec, to determine the conditions and circumstances which render picketing legal or illegal. Within this context, picketing will be examined from the point of view of object, form and occasion. In addition, the sanction of picketing will be presented, followed by a critique of the subject.

\section{LEGAL PICKETING}

Historical Perspective:

In the absence of specific legislation on picketing, freedom of speech could well constitute a legal basis for picketing. For example, the First Amendment to the American Constitution states that Congress cannot make any law which would abridge the freedom of speech or the right of people to peaceably assemble. While this principle has been recognized by the courts as a basis for picketing in the United States, the same cannot be said of Canada. In effect, there exists no equivalent statute to the First Amendment in our federal or provincial laws. In contrast, the right to picket in Canada developed initially through the courts' interpretation of British cases and later through an interpretation of what is now section 381(2) of the Criminal Code.

In England, during the 19th century, the law and the courts were consistently anti-labour. In fact, up until 1871, all organized labour activity constituted a «criminal conspiracy».

In 1871, legislation in England began to be directed towards improving the existing imbalance between labour and managernent. The Trade Union $A c t^{4}$ of 1871 established that the doctrine of conspiracy in the restraint of trade no longer applied to trade unions. Labour opposed this bill maintaining that the general provisions applicable specifically to trade unions should apply to the community at large. This protest resulted in separating the criminal provisions from those legalizing trade unions. These provisions were embodied in the Criminal Law Amendment Act. ${ }^{5}$ Labour, however, was still dissatisfied since

434135 Vict., c. 31.

534 and 35 Vict., c. 32. 
the said Act included a section which rendered "watching and besetting» an offence. The government finally introduced legislation, The Conspiracy and Protection of Property Act ${ }^{6}$ of 1875 which was acceptable to trade unions. Section 7 of this Act appeared to assure trade unions the right of peaceful picketing.

Legislation in Canada was adopted along the same lines as that in England. In 1972, the federal government enacted the Trade Unions $A c t^{7}$ which was similar to the Criminal Law Amendment Act ${ }^{8}$ of 1871. Following labour's protest, a new act was adopted in 1876. ${ }^{9}$. This Act was based substantially on the Conspiracy and Protection of Property $A c t^{10}$ of 1875 in which "watching and besetting " in order to communicate information was no longer a criminal offence. However, when criminal law was consolidated in 1892 in the Criminal Code ${ }^{11}$, the "peaceful picketing» clause was not included. Watching and besetting became an offence, and thus trade unionists who picketed during the course of a strike faced possible criminal prosecution for this activity.

Labour strenuously protested the omission of the «peaceful Picketing» section and demanded that the privilege of peaceful picketing be restored to them. The government finally ceded to their demands and amended the Criminal Code ${ }^{12}$ in 1934 so that according to Section 501, a person who attends a place for the purpose solely to obtain or give information does not commit the offence of intimidation by "watching and besetting». Article 381(2) which reproduces the 1934 amendment thus offers strikers protection from criminal prosecution for picketing in order to obtain or communicate information.

While the 1934 amendment established that picketing for the purpose of obtaining or communicating information was legal, the question lay in determining whether peaceful picketing, having the aim of persuading others not to work during a labour dispute was a tortious act enabling an employer to sue for damages and to take an action for injunction.

The two relevant cases cited in Canada as authorities on the issue were Lyons $v$. Wilkins ${ }^{13}$ and Ward, Lock v. O.P.A.S. ${ }^{14}$ In Lyons v. Wilkins $^{15}$, members of a trade union went on strike and established a picket line at the plaintiff's premises in order to persuade other employees to cease working. The defendants claimed that since they peacefully attempted to persuade workmen not to work, the activity did

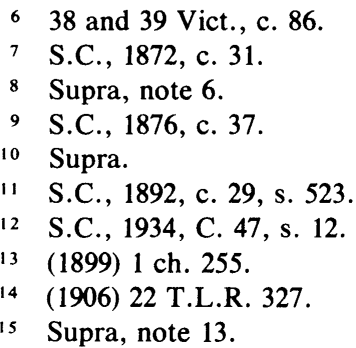


not fall within the provisions of section 7 (subsection 4) of the 1875 Conspiracy and Protection of Property Act.$^{16}$ The court, however, held that picketing constituted a common law nuisance. In reaching the decision that watching and besetting was a common law nuisance, section 7 of the said Act was interpreted to mean that: ${ }^{17}$

«the only case in which watching or beseting is allowed, or, in other words, is not unlawful, is that mentioned in the proviso at the end of the section - namely, where the attending at or near the house... or works... is in order merely to obtain or communicate information. Attending in order to persuade is not within the proviso."

Both Lindley, M. R., and Chitty, L. J., maintained that to watch or beset a man's house with the view to compel him to carry out or not carry out an activity was a wrongful act unless there was reasonable justification since such conduct interferes with the comfort and enjoyment of the «house beset».

In the case of Ward, Lock, ${ }^{18}$ an opposing point of view was taken. The defendant union placed its members around the plaintiff's business to persuade Ward, Lock's employees to join the union and cease working for their employer. Their object was to compel the plaintiff to employ union men only. An action was taken for damages and for an injunction to restrain the picketers from inducing breaches of contract, committing nuisance and watching and besetting. The court interpreted the words «wrongful and without legal authority» of section 7 of the Conspiracy and Protection of Property Act ${ }^{19}$ in a different manner from the previous case. Here, the court decided that the phrase "Wrongful and without legal authority» did not apply to the word compel. They only added a criminal remedy to acts for which there was already a civil remedy. Judge Moulton stated : ${ }^{20}$

«I cannot see that this section affects or is intended to affect civil rights or civil remedies. It legalizes nothing, and it renders nothing wrongful that was not so before.»

The judge added: ${ }^{21}$

"The restriction that the acts referred to must in themselves be at least civil torts is plainly expressed by the presence of the words "wrongfully» which applies equally to all classes... What, then is the effect of the exception which is made by the last paragraph of the section? In my opinion, that part of the section does exactly what its language expresses and no more. It expressly excepts a subclass of acts from the operation of the section...» ${ }^{20}$

\footnotetext{
16 Supra, note 7.

17 Supra, note 13 , p. 271.

18 Supra, note 14.

19 Supra, note 7.

20 Supra, note 14, p. 329.

21 Ibid, p. 329.
} 
Given this interpretation, the picketing was not found to be an offence within s. 7 of the Act and, therefore, did not constitute a common law nuisance.

In England, the two conflicting decisions were resolved by the Trade Disputes Act 22 of 1906. Specifically, section 2 of the Act assured workers of the right to picket peacefully. The purpose of picketing was not only for the purpose of obtaining or communicating information but also for the purpose of peacefully persuading others to work or abstain from working. There is, however, no equivalent to this section in $\mathrm{Ca}-$ nadian legislation. The question, therefore, was whether Lyons $v$. Wilkins ${ }^{23}$ of Ward, Lock ${ }^{24}$ applied. Both the doctrine and the majority of cases ${ }^{25}$ decided in favour of Ward, Lock ${ }^{26}$.

The controversy was finally resolved by the Supreme Court in Williams v. Aristrocratic Restaurants. ${ }^{27}$ Following a breakdown in contract negotiations, a trade union, certified as the bargaining agent of the employees in one of the employer's restaurants, set up a picket line in front of all the employer's restaurants. The picketers paraded with placards which truthfully stated that the employer had no agreements with the union. On appeal from a decision directing that the picketing be enjoined, the court held that the picketing did not constitute a nuisance. Reference was made to the English cases previously cited. With regard to Lyons $v$. Wilkins ${ }^{28}$, Judge Rand indicated that he could not follow the decision rendered if section 7 of the 1875 Act excluded compulsion as the object of picketing or if this section was taken to mean that compulsion cannot be brought about by persuasion. Hence he stated: ${ }^{29}$

«for what conceivable use or purpose would information be furnished if not to win support by the persuasive force of the matter exhibited?»

He concurred with the decision of Ward, Lock ${ }^{30}$ since in his opinion the conduct was justified by society's interest in the labour dispute and to compel by means or persuasion is a normal incident of industrial competition.

In addition the conduct was considered to fall within the provisions of s. 501 of the Criminal Code (now section 381 (2)) and section 3

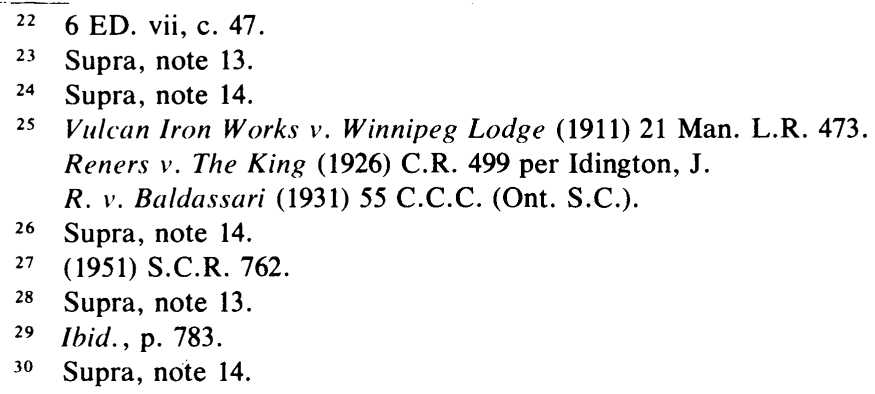


of the Trade-unions Act ${ }^{31}$. Section 3 of this Act not only absolves everyone from liability for communicating to any workman, artisan, labourer, employee or person, facts respecting employment but also removes liability for «persuading or endeavouring to persuade by fair or reasonable argument». ${ }^{32}$ Thus the court held that the manner of picketing was lawful according to both criminal law and civil law.

Although this case did not define with any appreciable precision the limits of peaceful picketing, it did determine that section 501 permitted this activity. Furthermore, the judgment established that picketing could go beyond obtaining or giving information, as set out in the section: picketing could be carried out in the form of peaceful persuasion. In this sense, Aristocratic Restaurants ${ }^{33}$ is a landmark decision.

\section{Present Status :}

Notwithstanding the absence of a formal definition of picketing in our laws, the doctrine and the courts ${ }^{34}$ have followed the precedent set by Aristocratic Restaurants ${ }^{35}$, and have continued to define peaceful picketing on the basis of section 381(2) of the Criminal Code. In sum, this section has been interpreted and has become accepted as providing the legal basis for peaceful picketing.

It is now an accepted principle, that workers have the right to picket for the purpose of obtaining and giving information and more specifically to advise and urge other workers to join a union or not to work. However, in achieving their aims, it is evident that picketers must respect the conditions established by the courts in order for the Act to remain lawful. These conditions deal with the form, object and occasion of a picket line.

\section{ILLEGAL PICKETING}

\section{Causes}

Form

Lord Lindley, in Quinn v. Leathem ${ }^{36}$ declared that a "combination not to work is one thing and is lawful. A combination to prevent others from working by annoying them if thcy do is a very different

\footnotetext{
31 R.S.B.C. 1948 , c. 342.

32 Supra, note 27, p. 797.

33 Ibid.
}

34 Nedco Ltd. v. Canadian Union of Communication Workers, Unreported Judgment, C.S. Montreal 05-0082-34-73, rendered 27 June, 1973; Borek v. Amalgamated Meat Cutters, (1956) C.S. 533; Ritz Carlton Hotel Co. Ltd. v. Union des Employés d'Hôtel, (1970) R.D. T. 28; Shane v. Lupovich, (1942) B.R. 523; General Dry Batteries v. Brigenshaw, (1951) 4 D.L.R. 41 Peerless Laundry v. Laundry \& Dry Cleaning Workers (1952) 4 D.L.R. 475 ; Arden Fur Corp. v. Montreal Fur Workers Union, (1966) C.S. 417.

\footnotetext{
35 Supra, note 27.
}

36 (1901) A.C. 495. 
thing and is prima facie unlawful $»{ }^{37}$ Similarly, in the case of Canadian Gypsum Co. Ltd. v. C.S.N. ${ }^{38}$ the court declared that a union and its members cannot take the law into their own hands to force an individual to stop working. According to this interpretation, the right to picket must, like any other right, be exercised so as not to interfere with the rights of others.

These judgments thus maintain that picketing which prevents other workers from entering their place of work is illegal. This illegality may take a number of different forms.

\section{Violence and Intimidation.}

Roy Heenan in his articles, «Strikes, Picketing and Injunctions in Quebec,» declared that: ${ }^{39}$

«it goes without saying that acts of violence and intimidation are illegal.»

This principle has repeatedly been affirmed by the Quebec judiciary. ${ }^{40}$ In Commission Hydro-Électrique de Québec v. L'Union Internationale des Journaliers Local 617 et autres ${ }^{41}$ the Court held that: ${ }^{42}$

«même une grève légale ne peut justifier un piquet illégal où l'on emploie l'intimidation, la violence, les menaces, la coercition..."

It is clear that the right to picket does not confer on picketers the right, through intimidation or violence, to prevent others from working. This principle is not only applied objectively but it also may be applied subjectively. The courts look beyond the actions of the picketers in a given situation. In other words, they look beyond the mere existence of intimidation or violence. In The Foundation Company of Canada Ltd. and International Fibre Board Ltd. $v$. The Building and Construction Trades Council of Hull \& District and other, ${ }^{43}$ it was established that the mere existence of a picket line, formerly intimidating and violent, would still serve as a constant reminder of past punishments and miseries, and of possible present and mostly probable future retaliation. ${ }^{44}$ Picketing was therefore declared illegal, albeit devoid of violence and intimidation. Thus, if any picket line, at a certain point in its existence, becomes violent and intimidating, it can be argued, in light of the

McGill L.J. 367 at p. 379.
$40 \quad$ Borek v. Amalgamated Meat Cutters, (1956) C.S. 533 ; Acton Vale Silk Mills Ltd. v. Léveilléelet autres, (1940) 78 C.S. 19; Bulk-Lift Systems v. Warehousemen \& Miscellaneous, (1975) 75 C.L.L.C. 726.

$41 \quad$ (1968) C.S. 10.

42 Ibid., p. 13.

43 (1961) C.S. 21.

44 Ibid., p. 22. 
above judgment, that the picket will forever be illegal since it serves as a constant reminder of this past activity. Such a criterion is not only subjective, conferring wide discretionary power to the judiciary, but also is highly arbitrary, serving to nullify the legal right to picket since it assumes a priori that there will be violence.

\section{Obstruction}

Independent of the question of violence and intimidation, if access to the picketed premises is blocked by the picketers, such an act is wrongful and without lawful authority. The problem lies in determining at what point the access is considered to be blocked. There seems to be little doubt as to the illegality of picketing when workers attempt to enter and are prevented from doing so (without the occurrence of violence of intimidation). ${ }^{45}$

Thus, any situation where a person wants to enter the picketed premises, and where such person is prevented from doing so, the picketing must be declared illegal. Consistent with this principle, the courts have condemned the practice of certain unions of establishing a «Pass System». Under this system, the union decides whom it will allow to cross the picket line, and issues passes to them. By implication, and in fact, any other operson is not allowed to enter. ${ }^{46}$ This system was declared illegal in the cases of Dominion Textile Company Limited $v$. Le Syndicat Catholique des Ouvriers du Textile de Magog Inc. (C.N.T.U. ${ }^{47}$ and Union Nationale des Employés de Vickers v. Canadian Vickers Limited. ${ }^{48}$

If no concrete obstruction exists, the question of the legality of the picket line is far more complex. Can the picketing be illegal if there exists no interference with any person attempting to pass through the picket line? In other words, if a person who of his own volition refuses to cross the picket line, is there an illegality? The courts seem reluctant to qualify picketing as illegal in such circumstances. In Nedco $v$. Clark and all other members of Communication Workers of Canada, Local no. 4,50 it was found that there were no grounds for restraining the lawful picketing of the respondent since the picketing did not interfere with any person passing on the sidewalk, with any customer or with any deliveries. Mr. Justice Culliton indicated that if any person refused to enter the picketed premises, they did so of their own will because they did not choose to cross a picket line. Hence their refusal to enter was not because of any obstruction preventing their entry to the building.

45 Tricot Somerset Inc. v. Le syndicat catholique du tricot Somerset Inc., (1954)

R.L. 93.

46 Supra, note 39 , p. 380.

47 Unreported judgment C.S. St-François 31,520.

48 (1958) B.R. 470.

$50 \quad$ (1973) 73 C.L.L.C. 184. 
From this and other judgments, ${ }^{51}$ it is evident that when there has been no obstruction, but employees will not cross a picket line due to their personal convictions, the picketing is not considered by the courts to be unlawful. It is only when picketing is of a nature to prevent the owner, his representatives or workers from peacefully reaching their place of work that it becomes an illegal act.

\section{Mass Picketing.}

A further consideration in determining the legality of picketing is the number of people forming the picket line. Does the mere presence of a large mass of picketers constitue an illegality? While in Lupovich $v$. Shane, ${ }^{52}$ it is stated that the numbers must not exceed "what is reasonably necessary ${ }^{53}$, this expression was not defined, thus leading to considerable ambiguity on this question. Does five, ten, fifteen, twenty, one hundred or one thousand picketers constitute a mass? Not only does this case not provide an answer but the number of permissible picketers has not been determined precisely in any case of «jurisprudence». Admittedly, in the decision where picketing was held to be legal, the numbers were small; for the most part, there were less than eight persons involved in the activity. However, the question as to what constitutes a mass still remains unanswered. It is therefore left to the discretion of the courts, according to the facts of each case.

\section{Right to Property}

The right to one's property imposes a further limitation upon picketing. Even peaceful picketing, when it infringes upon private property is considered to be an unlawful act: that of trespass. This interpretation is recent. The courts have not always viewed the right to property as absolute. The following cases illustrate the controversy that has surrounded this question which was resolved by the Supreme Court decision of Harrison v. Carswell. ${ }^{54}$

In Grosvenor Park Shopping Centre Ltd. v. Waloshin, ${ }^{55}$ a shopping centre owner instituted an action in trespass and by means of an injunction attempted to restrain his tenant's employees from picketing on the sidewalks adjacent to the store premises during a legal strike. The Saskatchewan Court of Appeal rejected the respondent's action. Their decision was based on the fact that since the owner has extended an unrestricted invitation to the public to enter upon the premises, the respondent no longer had exclusive possession.

However, the Ontario Court of Appeal in Regina v. Peters ${ }^{56}$ rejected the idea that an owner who invited the public onto his premises thereby lost the right to maintain an action in trespass.

51 Sasso Disposal Ltd. v. Webster, (1976) 10 O.R. (2d) 304; supra, note 1.

52 (1944) 3 D.L.R. 193.

53 Ibid., p. 203.

54 (1975) R.C.S. 200.

55 (1965) 46 D.L.R. (2d) 750.

$56 \quad$ (1970) 16 D.L.R. (3d) 143. 
This decision was appealed to the Supreme Court of Canada which, when faced with two conflicting Court of Appeal judgments, adopted the position of the Ontario Court of Appeal.

The controversy as to whether or not an owner who has extended an unrestricted invitation to the public, exercises control over his property to the exclusion of other persons was finally resolved in the Carswell ${ }^{57}$ case. In this judgment, the respondent Carswell, who was an employee of a tenant in a shopping centre, peacefully picketed the premises of her employer while participating in a legal strike. The picketing which was exercised directly in front of the struck premises was on private property. The respondent was informed by the owner of the shopping centre that picketing was not permitted in any area of the shopping centre and was advised to move to a public sidewalk, some distance away. Carswell's refusal to leave the premises and to cease picketing resulted in four charges against her under the Petty Trespasses Act ${ }^{58}$ In reaching their decision, the Supreme Court rejected a technique commonly used by American Courts known as the «balancing of interest ${ }^{59}$ which in this instance would require the Court to weigh and determine the respective values to society of the right to property and the right to picket. The Court refused to view the issue in terms of this conflict, claiming that such an approach would raise difficult political and social issues, the consideration of which could be resolved only in an arbitrary manner and embody personal, economic and social beliefs. Hence, the Court held that the owner of a shopping centre had sufficient control or possession of the common areas, notwithstanding the unrestricted invitation to the public to enter upon the premises, to enable him to invoke the remedy of trespass. Judge Dickson who delivered the majority decision stated: ${ }^{60}$

«Anglo-Canadian jurisprudence has traditionally recognized, as a fundamental freedom, the right of the individual to the enjoyment of property and the right not to be deprived thereof, or any interest therein, save by due process of law. The Legislature of Manitoba has declared in The Petty Trespass Act that any person who trespasses upon land, the property of arother, upon or through which has been requested by the owner not to enter, is guilty of an offence.»

In Quebec, the Courts have based the «right of property" on both the Civil Code (art. 399 and 406) and the Criminal Code (art. 501). ${ }^{61}$ It appears from an interpretation of these articles and certain provincial Acts, ${ }^{62}$ that peaceful picketing will not be tolerated when it infringes

57 Supra, note 54.

58 R.S.M. 1970, c p-50.

59 S. COVAL et al, «The Supreme Court and a New Jurisprudence for Canada»

(1975) $53 \mathrm{R}$ du B. Can. 819 at pp. 823-824.

60 Supra, note 54, p. 219.

61 Noranda Mines $v$. The United Steelworkers of America, (1954) C.S. 27; Supra, note 43; General Dry Batteries of Canada v. Brigenshaw, (1951) 4 D.L.R. 414.

62 Supra, note 58. 
upon private property. Therefore, persons engaged in picketing cannot carry out their activity on the personal property of their employer, nor in any way damage his property. It follows that in order to constitute a legal activity, the picketing must take place on public grounds.

Object.

Picketing, apart from being illegal on the basis of its form, may also be rendered illegal by its object. Object for purposes of this study, signifies intent or purpose. As Viscount Simon stated in the case of Crofter Hand-Woven Harris Tweed Co. Ltd. v. Vertch: ${ }^{63}$

"The rest is not what is the natural result to the plaintiffs of such combined action, or what is the resulting damage which the defendants realize or should realize will follow, but what is in truth the object in the minds of the combiners when they acted as they did.

It is not consequence that matters, but purpose.»

The principle will be analyzed in two separate sections. First, we will deal with the general principle of scheming to injure the operations of a company, and in a further section, we will deal with this notion relative to the question of placards (see section on placards relative to true statements).

\section{Scheming to Injure}

Picketing will be legal if the picketers' intent is to promote the interests of the union, but it will be illegal if their intent is to injure the interests of the employer. This distinction has been frequently cited by the Quebec Courts. ${ }^{64}$ In Seafarers' International Union of Canada $v$. Upper Lakes Shipping Limited ${ }^{65}$ members of the Seafarers' Union picketed the premises of their former employer, Upper Lakes Shipping. The evidence, as cited by the court, established that tug-boat crews refused to tow respondent's vessels; that truckers, members of a labour union, refused to carry cargo from these vessels; and that a party of three crew-members from one of these vessels were attacked in the street by seven men. On the basis of these incidents, the court reasoned that the picketing was part of a scheme to prevent the carrying on of respondent's business.

It is apparent that the courts have further restricted picketing by creating a subjective criterion. Not only must picketing be legal according to its form (subject to the objective criteria cited previously) but it must also be legal according to its object. Thus picketing carried out in a peaceful manner, but with the object of injuring the employer's business will be illegal. We have seen, however, that the determination of what constitutes intent to injure the interests of the employer and intent to promote interests of the union is not easily distinguished. This naturally has the effect of leaving a great deal of discretion to the courts.

63 (1942) A.C. 435 at p. 445.

${ }^{64}$ Noe Bourassa Limitée v. United Packinghouse Workers of America, (1961)

C.S. 604 .

65 (1964), B.R. 737. 


\section{Placards.}

\section{a) Intimidating placards}

The courts have ruled that picketing is illegal if placards or other literature is intimidating. This opinion was clearly expressed in the case of Hurtig v. Reiss. ${ }^{66}$ While the expression "intimidation» has not been defined in the context of placards, we must assume that any placard which inspires a legitimate fear would fall into this category. In the Rother ${ }^{67}$ case, the Court of Appeal stated that if things done, or words spoken or written excite fear or a reasonable apprehension of fear or danger and so influence those for whom it is intended so as to prevent them from freely doing what their desire and the law permits, they may be so restrained. ${ }^{68}$ Thus, it would appear that the mere presence of an intimidating placard would render the picketing illegal independent of its peaceful manner.

\section{b) Defamatory Placards}

Black's Law Dictionary defines defamation as: ${ }^{69}$

«the offence of injuring a person's character, fame, or reputation by false and malicious statements.»

In general, the question of defamation arises in a civil suit for damages. This principle, however, can also be raised as a cause for an illegal picket.

False Statements

In order for defamation to render picketing illegal, there must be proof of a fault. The first characteristic «est celle où le défendeur, sciemment de mauvaise foi, avec l'intention de nuire, s'attaque à la réputation de la victime et cherche à le ridiculiser ou l'humilier, à l'exposer à la haine ou au mépris du public ou d'un groupe ». ${ }^{70}$ Secondly, defamation can also exist without the will of bad faith, provided that the information is false and the reputation is damaged. Thus, where picketers knowingly or unknowingly damage the reputation of a «moral or physical person» through false information contained on placards, the picketing becomes illegal.

We must note, however, that statements on placards that are partially misleading or false, do not necessarily create illegal picketing. In Ritz Carlton Hotel Co. Ltd. v. l'Union des Employés d'Hôtel, ${ }^{71}$ the court expressed the opinion that while the statements on placards in

\footnotetext{
66 (1937) 69 C.C.C. 101.

67 International Ladies Garment Workers Union v. Rother, (1923) 34 B.R. 69.

68 Ibid., p. 69.

69 Black's Law Dictionary, Henry Black, (St. Paul, 1968), p. 234.

70 Jean-Louis BEAUDOIN, La Responsabilité civile délictuelle, (Montreal,

71 Supra, note 34.
} 1973), p. 129. 
that case may not have been literally true, they were not patently false considering the circumstances and the limitation of space in making propaganda by placard. This has raised doubt as to what constitutes a «patently false» and «literally true» statement. Nowhere in this case or in subsequent case have these terms been defined. It thus follows that the Courts are again left with wide discretion in adjudicating upon this question.

\section{True Statements}

Defamation can occur even if placards paraded are true. Such is the case of a placard which has as its only goal to harm the victim. In the case of Hurtig v. Reiss, ${ }^{72}$ the veracity of these statements on the placards was upheld by the court. Despite this conclusion, however, the court held that the parades in which these placards were carried, and the appeal to the public not to buy the employer's goods indicated that their purpose was to injure his business. An injunction was thus issued forbidding the carrying or displaying of placards or posters which would tend to injure the plaintiff's business.

Further illustrations of this principle can be found in the cases of Allied Amusements v. Reaney ${ }^{73}$ and R. v. Baldassari. ${ }^{74}$

In contrast, placards with truthful statements paraded with the intent of conveying information to the public are legal. In the case of $\mathrm{Bel}$ lemare Datsun v. Automobile Protection, ${ }^{75}$ the respondent, having discovered that the plaintiff sold 1972 cars as 1973 cars, picketed the premises of said plaintiff for purposes of informing and warning the public of this practice. The court judged the picketing to be legal, contending that the intent of the respondent was not to harm the plaintiff's business by reducing sales, but on the other hand to communicate information to the public.

In the case of Wasserman v. Sopman, ${ }^{76}$ picketing was found to be legal where members of a firm of poultry commissioners were, in a peaceful fashion, parading signs truthfully stating that such dealer refuses to deal with the picketers' firm. In this judgment, there was no intention on the part of the picketers to injure the plaintiffs, and consequently the picketing was legal. The court further established that even if the effect of the placards is to engender loss of trade, an injunction cannot be issued.

We can thus conclude that picketing is legal when: 1) information conveyed on the placards is truthful, and 2) the picketers do not have the intent to injure the plaintiff's business. The prime consideration in the legality of a picket line is the intent of the picketers and not the actual effects that their activities may engender.

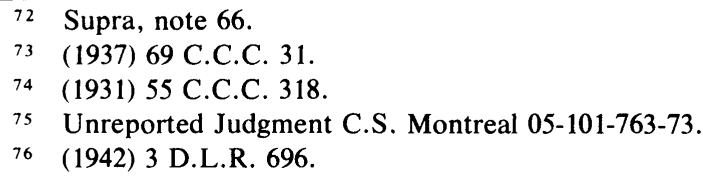




\section{Occasion}

\section{Illegal Strikes}

We have seen from the foregoing that when any one of a number of illegal acts have been committed in the «form» or the «object» of picketing, the activity consequently becomes illegal. A problem arises in instances where the picketing is in itself peaceful (i.e. not illegal in terms of its «form» or «object») but is carried out to further an illegal strike. The question as to the legality of the picketing under these circumstances has arisen in numerous decisions during the past three decades. A review of the «jurisprudence» reveals conflicting positions taken by the courts over the years.

During the 1950's, the tendency of the courts was to view peaceful picketing as lawful, whether or not the strike was legal. ${ }^{77}$

This attitude with regard to peaceful picketing was reversed in the early 1960's by a Supreme Court judgment in Gagnon et al. v. Foundation Maritime Limited. ${ }^{78}$ In this case, officials of the company refused a request made by union organizers for recognition of their union since they had not been certified as required under the Labour R'elations Act. ${ }^{79}$ Subsequent to the company's decision, a picket line appeared which had the effect of bringing the operations of the company to a standstill. The New Brunswick Supreme Court issued an injunction against the picketing, despite its peaceful nature, on the grounds that as the strike itself was unlawful, the picketing was unlawful. This decision was maintained by the Supreme Court.

The notion derived from the Gagnon ${ }^{80}$ case, that the illegality of a strike necessarily renders the concomitant picketing illegal has, with few exceptions, been accepted by the courts up to the present time. ${ }^{81}$

77 General Dry Batteries of Canada Ltd. v. Brigenshaw, (1951) 4 D.L.R. 414; Peerless Laundry v. Laundry and Dry Workers Union et al, (1952) 4 D.L.R. 475 ; Borek v. Amalgamated Meat Cutters, (1956) C.S. 533 ; Oberman et al. v. Amalgamated Meat Cutters and Butcher Workmen of North America, Unreported Judgment C.S. Montreal 388, 146 rendered 7 March, 1956; Hyde Park Clothing Limited v. Amalgamated Clothing Workers of America, Unreported Judgment C.S. Montreal 442, 402 rendered 20 May, 1958; Windsor Shoe and Slipper Co. v. Union des Ouvriers de la Chaussine, Local 400, (1954) B.R. 266.

78 (1960) S.C.R. 435.

79 R.S.N.B. 1952 , c. 124.

80 Supra, note 78.

81 Freight-Aid Ltd. v. The Cartage and Miscellaneous Employees, Local 931, Unreported Judgment C.S. Montreal 706,599 rendered 15 March, 1966; Sanguinet Automobile Limitée v. La Fraternité Canadienne des Cheminots Employés des Transports et autres ouvriers, Local 511, et autres (1964) C.S. 544; Vapor Heating v. United Steelworkers of America, et al, Unreported Judgment, C.S. Montreal 709,636, rendered 19 April; 1966; Queen Elizabeth Hospital of Montreal v. Raoul Gagnon, et al., Unreported Judgment, C.S. Montreal 724,006, rendered 12 January, 1967. 
A few decisions in the latter period of the 1960's had been interpreted as a renewed reversal of the position of the courts. ${ }^{82}$ For example, in the case of Arden Fur Corp. v. Montreal Fur Workers Union ${ }^{83}$, the company requested that the court grant an injunction to stop the picketing which took place in front of the business premises. Mr. Justice Petticombe did not find the conduct of the picketers to be reprehensible. He reffered to be decision of Hyde Park Clothes Ltd., ${ }^{84}$ where Mr. Justice Challies indicated that peaceful picketing should not be enjoined even when it is in support of an illegal strike. His approval of the principle is evident since he applied this reasoning to the present case in which no strike existed and dismissed the application for an injunction.

Further decisions, however, indicate that this favourable attitude towards peaceful picketing accompanying an illegal strike did not continue. The interruption of the tendency established in the early 1960 's was only temporary. Evidence of this may be found from Judge Deslaurier's statement at p. 40 in Imprimerie Montréal, Offset Inc. v. l'Union Typographique Jacques-Cartier: ${ }^{85}$

«Si l'arrêt de travail constitue une grève et si cette grève est exécutée en violation des dispositions formelles de la loi, le tribunal est d'opinion que tout guet, même paisible, devient illégal à moins qu'il ne soit autorisé par une disposition législative édictée à cette fin.»

In the decision of Thomson Electrical Works v. McGraw et al, the defendants, who were engaged in picketing, were not members of a trade union. The Court stated that since the defendants were not carrying out a lawful union activity, they had no right to picket. The court came to a similar conclusion in Rudolf Martin Enterprises Ltd. and Laukkanen Construction Ltd. v. International Union of Elevator Constructors, ${ }^{87}$ and Masco Construction Ltd. v. International Union of Operating Engineers. ${ }^{88}$

It is evident that the Courts have considered picketing, even when peaceful, to be illegal where it is carried out in support of an illegal strike or where this activity has taken place in violation of any relevant legislation. Given that the latter judgments cited are recent, it may be concluded that this is the present position of the judiciary.

82 United Steel Workers of America v. Gaspe Copper Mintes Ltd., (1967) B.R. 487; Conseil des Ports Nationaux v. International Longshoremen's Ass., 1968 R.D.T. 15.

83 Supra, note 34.

84 Hyde Park Clothes Ltd. v. Amalgamated Clothing Workers of America, Unreported Judgment C.S. Montreal 443, 402, rendered 20 May, 1958.

85 (1968) R.D.T. 28.

86 (1975) 11 N.B.R. (2d) 427.

87 (1973) 73 C.L.L.C. 29.

88 (1977) 17 N.B.R. (2d) 516. 
Sanction: The Injunction.

General notions

The injunction is the common sanction against illegal picketing. While the illegality of picketing can also result in criminal proceedings and civil suits, we will focus our attention on the question of injunctions.

Injunctions are divided into two separate categories. First, injunctions are either restrictive or mandatory. This refers to the nature of the order issued pursuant to the petition. The second classification comprises injunctions which are either interlocutory or final. This category refers to the mode and timing of the petition.

The most common form of injunction, the restrictive injunction, orders a party (the defendant) not to do or to cease doing a certain act. It is this injunction which commonly sanctions illegal picketing. On the other hand, the mandatory injunction orders the respondent to do or perform a certain act. Article 751 CCP states that the mandatory injunction is only available «in cases which admit of it», namely those instances where specific performance is the appropriate solution.

Injunctions are also classified according to the mode and timing of the petition. The interlocutory injunction may be obtained either at the beginning of the principal action or at any time during the suit (article 752). Its primary purpose is to preserve the status quo until judgment on the principal action has been rendered. Article 753 states that the interlocutory injunction must be applied for by a motion to the court supported by an affidavit affirming the truth of the facts alleged. Furthermore, it must be served upon the opposite party with mention of the date when it will be presented.

The interim interlocutory injunction is an exceptional form of the interlocutory injunction. While obtained in the same manner as the ordinary interlocutory, it is not served on the opposite party, thereby denying the said party the opportunity of refuting the allegations contained therein. Moreover, article 753 restricts the use of the interim injunction to cases of extreme urgency. Consistent with this principle, the court in Tricot Somerset Inc. V. Le Syndicat Catholique ${ }^{89}$ considered «qu'il était donc urgent et impérieux de décerner une injonction intérimaire de façon à mettre fin au piquetage». Finally, we must note that the interim injunctions cannot be granted for a period exceeding ten days and, in fact, is rarely granted for more than five days.

The interlocutory injunction, whether ordinary or interim, is governed by the criteria set down in article 752 , par. 2., C.C.P. This article states that injunctions may be granted on an interlocutory basis only if the petitioner establishes a prima facie case in his favour, and is suffering serious or irreparable damage. In applying these criteria, the courts use what is known as the "balance of inconvenience» theory. 
Thus, an injunction will be granted only when the alleged injury to the petitioner is greater than the prejudice to the respondent should the injunction be accorded. The court must in effect balance or weigh the inconvenience that each party might suffer depending on whether the injunction is granted or not.

The final injunction, on the other hand, is sought as the conclusion of the principal action. The procedural requirements governing such an injunction are similar to those governing all principal actions where the fault alleged is outlined in the writ and served on the opposite party. The court, in such cases, is not concerned with prima facie rights. Instead it will restrict itself to the consideration of real rights in deciding whether to grant or refuse an injunction. We must note that in determining the merits of an application for a final injunction, the court will not use the criteria outlined in article 752 , C.C.P. relative to the granting of an interlocutory injunction.

In labour disputes, the injunction is most frequently used to restrain unlawful picketing by strikers or others at the employer's or someone else's place of business. Previously, we have seen that picketing may be illegal because of its form, object or occasion. In any of these instances where picketing is illegal, the petitioner may apply for an interlocutory or interim injunction even before the merits of the case have been judged. Where an act is held to be illegal, an injunction generally will be granted. We must note, however, that the question of whether to have an injunction and what is in fact enjoined by an injunction is the decision of the presiding judge. Finally, we must add that if picketing is declared legal, no injunctions will be granted, be it interlocutory, interim or final.

Criticisms

Numerous criticisms have been levied against the injunction, particularly of the interlocutory type. For example, Carrothers contends that it is granted in language broader than the circumstances warrant, and in legal phraseology often incomprehensible to the laymen. ${ }^{90}$ Other complaints are cited by Mr. Justice Laskin in «The Labour Injunction in Canada. ${ }^{91}$ These include the far-reaching terms of the order creating fear in those who are enjoinded, the circumscription of union activity beyond the needs of the particular case and the prejudgment of the issues involved in a labour dispute. It also has been found that injunctions produce resentment and antagonism that frequently result in acts of violence which did not exist prior to the injunction order.

The most common criticism of the injunction is that it is generally granted ex parte. In this case, the party petitioning the court for an injunction files affidavits containing allegations of fact which naturally is prejudiced in his favour. The deponents are not cross-examined nor is

90 A.W.R. CARROTHERS, The Labour Injunction in British Columbia, Toronto, 1956, p. 202 and 209.

91 (1937) 15, Can. B. Rev., 270 at p. 272-273. 
their evidence, often on information and belief, tested in any other way. Based upon this evidence, the judge decides whether or not the petitioner has a prima facie case required for the issuance of an injunction. The merits of the case are not considered at this point. The opposing party not only is absent but is not notified of the hearing and thus has no possibility of refuting the allegations. It follows that the party enjoined is not even aware of the existence of the court order until it is served upon him.

In our estimate, this procedure violates the rules of natural justice, specifically that of the rule «audi alteram partem» since the effect of the ex parte injunction is to deprive one of the parties of his rights without having had the opportunity to be heard by the court. It is impossible for the court to claim that its judgments are made objectively when only one of the parties to the dispute has been presented.

Furthermore, since it is normal for the employer to present arguments in his own favour and interpret the facts to his advantage, and since the union is not present at the hearing, it is not surprising that ex parte injunctions are granted so readily. Thus, the fact of not taking the other party into account not only violates a fundamental right, the right to be heard, but results in a prejudice in favour of the petitioner.

It may be argued that since the issues are determined at trial, there is no need for labour to be heard at the time of the ex parte hearing. ${ }^{92}$ In actual fact, the majority of cases never reach trial on the merits. Viewed in this light, any claim that consideration is given to unions' interests appears to be unfounded.

Others defend the injunction on the grounds that it may be appealed. Given this recourse, it is argued that in cases where the injunction was granted without justification it will be dismissed and damages awarded. In reality, however, the removal of an injunction at a later date is of little value. The decision in Canuk Lines Limited v. Seafarer's International Union of Canada and others ${ }^{93}$ clearly illustrates this point. In this case, Canuk, owner of the S.S. Canuk, fired all his crew members in Hong Kong in order to free himself of a collective agreement he had signed with the Seafarer's International Union (S.I.U.). According to the agreement the ship was to be manned by a crew composed of Canadians who were members of the S.I.U. He then hired a new crew composed entirely of Hong Kong nationals at rates considerably lower than those in effect in Canada. In 1962, when the S.S. Canuk Trader arrived in Montreal, the S.I.U. established a picket line to publicize the fact that its members had been fired. Because of the refusal of the stevedores of the International Longshoremen's Association to cross the picket line, Canuk petitioned for and obtained first an interim injunction and then an interlocutory injunction in August, 1962. On Octobre 31,1963, more than a year from the time the interim injunction was issued, the court decided that the damages suf-

\footnotetext{
92 Supra, note 90 , p. 207.

93 (1966) C.S. 543.
} 
fered by Canuk were not caused by the Union simply because the Longshoremen respected the picket line. The court held that the S.I.U. had the right to establish a picket line to protect the interests of its members since the employer had broken the collective agreement. While it was decided that a picket line could be established legally, this proved to be little consolation for the union. In effect, by the time the judgment was rendered, the ship had long departed. In light of this fact, it is evident that the re-establishment of a picket line would have had no purpose. In addition, it must be noted that the S.I.U. dit not obtain any damages for the prejudice incurred by the issuance of the injunction.

The injunction is not the only recourse available to the employer for a breach of contract, infringement upon property or a criminal charge. However, during the course of a labour-management struggle a criminal suit or other civil actions are in no way as effective as the injunction. These procedures can drag on for months if not years. In addition, they do not prevent the recurrence of picketing or other union acts. The injunction, on other hand, provides management with immediate results and forces compliance with the court order. Thus the injunction is used frequently by management rather than alternate legal procedures. If we recognize that a certain equilibrium must exist between labour and management during a labour dispute, then the position of the workers is seriously affected when the right of picketing has been removed. When a court order is issued to halt picketing, it not only compromises the union's position for the duration of the labour dispute but it has the effect of eliminating one of the essential weapons that workers possess in the dispute. The tactic of having picketing enjoined demoralizes the workers and breaks their solidarity. In fact, once an injunction is granted enjoining picketing, it can effectively have the consequence of breaking a strike. Thus, this tactic successfully produces a destabilizing effect in the relations between the two parties.

In light of the above, if the balance of inconvenience test is to be applied strictly, the injurious effect of the injunction on labour's activities must be considered to the same extent as the irreparable injury to management. Given the frequency with which injunctions are granted to the employer this does not seem to be the case at present. It appears evident that some changes are warranted in order to arrive at a solution which would be acceptable and just to both parties.

\section{CONCLUSION}

It has been recognized by law that workers have the right to group themselves into associations; to form and negotiate collective agreements and to engage in strikes. Because of the growing importance of the labour movement in the past century, it became essential to legislate on these and other areas of labour relations. Hence, the Labour Code indicates the requirements which must be met in order for the various rights of labour to be recognized. Therefore, it is illogical that picketing, a common element in labour disputes, has not been 
codified in our laws. The absence of such legislative provision has left the judiciary with an unwarranted degree of discretion. The Courts thus determine the legality of a picket on purely subjective criteria. This was underlined in the cited cases of mass picketing, obstruction and even of violence. In the latter situation, in the case of Foundation, the mere existence of a picket line served as a constant reminder of past threats. Thus, while the picketing was peaceful in this case, the Court's interpretation rendered the picketing illegal because of some imagined apprehension. Furthermore, we may add that apart from the determination of the legality of the picket, the Courts have almost complete discretion in deciding upon the ultimate sanction of such illegality - the injunction.

Although a certain element of discretion is exercised in any judicial decision, these decisions are based on the interpretation of an existing law. Such is not the case in the realm of picketing. Given the absence of any legislative authority, the Courts set their own guidelines. Their discretion is thus absolute. The authors feel that this situation is untenable.

Moreover, the judiciary has usurped the role of the legislator in this domain. In effect, when a judge declares the illegality of picketing and issues an injunction, he becomes the private legislator of one party against the other. Thus, we find the anomaly of one individual concurrently exercising two powers, that is the legislative and the judiciary.

Finally, we feel that the judicial branch is unable to deal impartially with the issue of picketing. Because of his background, the judge will likely be found to share the same values as the employer, and will be more disposed to support the values that uphold these rights. The following statement by Lord Scrutton in an address delivered before the University Law Society, although made more than five decades ago has some pertinence even today: ${ }^{94}$
«I am not speaking of conscious impartiality; but the habits you are trained in, the people with whom you mix, lead you to having a certain class of ideas of such a nature that when you have to deal with other ideas, you do not give as sound and accurate judgments as you would wish. This is one of the great difficulties at present with Labour. Labour says: Where are your impartial judges? They all move in the same circle as the employers, and they are all edu- cated and nursed in the same ideas as the employers. How can a labour man or trade unionist get impartial justice? It is very difficult sometimes to be sure that you have put yourself into a tho- roughly impartial position between two disputants, one of your own class and one not of your class.»

What are the solutions to this complex issue? Proposals have ranged from a stricter application of the law to the total abolition of the use of injunctions in labour conflicts. 
A.W.R. Carrothers in this book The Labour Injunction in British Columbia, ${ }^{95}$ adopts a rather conservative position with regard to the problem of labour disputes. While recognizing that certain abuses exist, he does not advocate curbing the use of the injunction or modifying the law. According to the author, the basic problem concerns the procedures by which it is obtained and the form that the order takes. His proposals therefore deal with both the form and the procedure of the injunction. For example, he suggests that affidavits on information and belief should be avoided except in cases of imperative need. Concerning ex parte injunctions, he urges that particular care should be taken to see that the qualifications of fairness and explicitness are met. Taken as a whole, his proposals amount to nothing more than a stricter application of the law while leaving the same discretionary powers to the judges. He concludes his critique and summary with the following statement: 96

"A number of the above suggestions are not rigid requirements of the law. But if they are followed it is submitted that it cannot be said with truth and justification that through the abuse of the injunctive process there is one law for management and another for labour.»

The implication of this proposal is that if unions and management adhere to and obey the law all injustice will be eliminated. The authors do not consider that his proposals alter the present injustices or offer any concrete solutions to the labour-management problem.

At the other end of the spectrum, labour advocates the total abolition of the injunction in labour disputes. La Confédération des Syndicats Nationaux, for example, views the injunction as a weapon used by management to deprive labour of an effective means of retaliation. The following passage illustrates their reasoning for opposing the injunction: ${ }^{97}$

«... On peut ajouter qu'une injonction joue contre les groupes qui, non seulement tentent de rétablir l'équilibre entre le pouvoir considérable, qui les tient et le pouvoir subordonné et insuffisant qui est leur lot, mais cherchent à réaliser pour eux-mêmes des choses d'une importance vitale: meilleurs salaires, sécurité d'emploi plus grande, moyens de défense contre les abus quotidiens de l'autorité dans l'entreprise, sécurité et hygiène au travail...»

The total abolition of the injunction (against picketing), in our opinion, can only lead to discrimination toward management which would be as unjust as the present use of injunctions is against labour.

95 Supra, note 90 .

96 Ibid., p. 215.

97 Pour l'abolition de l'injonction dans les conflits de travail, La Confédération des Syndicats Nationaux: Montréal, le 8 mars, Réimpression et nouvelle Présentation - Nov. 1960, p. 5-7. 
Therefore, the following solutions are more acceptable to the authors:

1. Picketing must be codified not only in terms of its definition but in all aspects; for example, the number of picketers permitted at each entrance of the picketed premises, the permissible communication on placards, a clear-cut definition of intimidation and obstruction, and so on. Moreover, we recommend the formation of an administrative mechanism to determine the norms and application of these legislative criteria.

This type of legislation would minimize the Court's present discretionary powers while in no way negating the rights of labour to use what has become a most important weapon in labour disputes.

2. We recommend the establishment of a labour court composed of members of labour, management and the law. This composition would avoid the partiality that is said to exist among judges who identify with management rather than labour. In addition, the court would deal with all aspects of labour disputes. We make this recommendation bearing in mind the existence of arbitration boards because we see the powers of the Labour Court being more extensive then those exercised by the labour arbitration boards. We suggest that the powers to grant injunctions in labour disputes be removed from the Superior Court and given to this Labour Court. The authors' prime objection to the injunction is due to the arbitrary manner in which they are issued, the possible partiality of the judges and the usurpation of the legislative function rather than the injunction per se. It is suggested that injunctions can be permitted if precise legislation as to their issuance is enacted, limiting injunctions to exceptional circumstances also precisely defined by law. This would have the effect of removing the present judicial prejudice against picketers while at the same time acknowledging the rights of management. Needless to say, ex parte injunctions, in that they violate the fundamental right of one of the parties to be heard, must be abolished.

To sump up, it is evident that the whole area of picketing in its various manifestations should be reviewed by the legislative and judicial authorities in order to produce a more equitable set of guidelines for both labour and management. In the absence of reform, the present acrimony and uncertainty will continue unabated. 


\section{BIBLIOGRAPHY}

Cases Judicially Noticed:

Acton Vale Silk Mills Ltd. v. Léveillée et autres, (1940) 78 C.S. 19.

Allied Amusements v. Reaney et al., (1937) 69 C.C.C. 31.

Arden Fur Corp. v. Montreal Fur Workers Union, (1966) C.S. 417.

Bellemare Datsun v. Automobile Protection Association, Unreported Judgment C.S. Montreal \#05-010-763-63.

Board of School Trustees of School District no. 61 v. Canadian Union of Public Employees, (1977) 71 D.L.R. (3d) 139.

Borek v. Amalgamated Meat Cutters, (1956) C.S. 533.

Buld Lift Systems Ltd. v. Warehousement \& Miscellaneous, (1975) 75 C.L.L.C. 726.

Canadian Gypsum Co. Ltd. v. C.S.N., (1973) C.A. 1075.

Canuk Lines Limited v. Seafarer's International Union of Canada and others, (1966) C.S. 543.

Conseil des Ports Nationaux v. International Longshoremen's Ass., (1968) R.D.T. 15.

Commission Hydro-Électrique de Québec v. l'Union internationale des Journaliers Local 617 et autres, (1968), C.S. 14.

Crofter Hand-Woven Harris Tweed Co. Ltd. v. Vertch, (1942) A.C. 435.

Dominion Textile Co. Ltd. v. Le Syndicat Catholique des Ouvriers de Textile de Magog Inc., Unreported Judgment, C.S. St-François 31,520 rendered 25 April, 1966.

Freight-Aid Ltd. v. The Cartage \& Miscellaneous Employees Local 931, Unreported Judgment C.S. Montreal 706,599 rendered 15 March, 1966.

Gagnon, et al. v. Foundation Maritime Limited, (1960) S.C.R. 435.

General Dry Batteries v. Brigenshaw, (1951) 4 D.L.R. 414.

Grosvenor Park Shopping Centre Ltd. v. Waloshin (1965) 46 D.L.R. (2d) 750.

Harrison v. Carswell, (1975) R.C.S. 200.

Hurtig v. Reiss, (1937) 69 C.C.C. 101.

Hyde Park Clothes Ltd. v. Amalgamated Clothing Workers of America, Unreported Judgment C.S. Montreal 442,402 rendered 20 May, 1958.

Imprimerie Montréal Offset Inc. v. l'Union Typographique Jacques Cartier, (1968) R.D.T. 28.

International Ladies Garment Workers Union v. Rother, (1923) B.R. 34.

Lupovich v. Shane, (1944) 3 D.L.R. 193.

Lyons v. Wilkins, (1899) 1 ch. 255.

Masco Construction Ltd. v. International Union of Operating Engineers, Local 946, (1977) 17 N.B.R. (2d) 516.

Nedco v. Clark, (1973), 73 C.L.L.C. 184.

Nedco Ltd. v. Canadian Union of Communication Workers, Unreported Judgment C.S. Montreal 05-0082-34-73, rendered 27 June, 1973.

Noe Bourassa Ltée v. United Packing House Workers of America, (1961) C.S. 604.

Noranda Mines v. United Steelworkers of America (1954) C.S. 27.

Oberman et al. v. Amalgamated Meat Cutters and Butcher Workmen of North America, Unreported Judgment C.S. Montreal 338,146 rendered 7 March, 1956.

Peerless Laundry \& Cleaners v. Laundry \& Dry Cleaning Workers Union et al, (1952) 4 D.L.R. 475.

Queen Elizabeth Hospital of Montreal v. Raoul Gagnon et al., Unreported Judgment C.S. Montreal 724,006 rendered 12 January, 1967.

Quinn v. Leathem, (1901) A.C. 495.

R. v. Baldassari, (1931) 55 C.C.C. 318. 
Regina v. Druitt (1867) 10 Cox C.C. 592.

Regina v. Peters, (1970) 16 D.L.R. (3d) 146.

Reners $v$. The King, (1926), S.C.R. 499.

Ritz Carlton Hotel Co. Ltd. v. L'Union des Employés d'Hôtel, (1970) R.D.T. 28.

Rudolf Martin Enterprises Ltd. \& Oliver Laukkanen Construction Ltd. v. International Union of Elevator Constructors, Local 82, (1973) C.L.L.C. 29.

Sanguinet Automobile Limitée v. La Fraternité Canadienne des Cheminots employés des Transports et autres ouvriers, Local 211, (1964) C.S. 544.

Sassco Disposal Ltd. v. Webster, (1976) 10 O.R. (2d) 304.

Sauvé Frères v. Amalgamated Clothing Workers of America, (1959) C.S. 341.

Seafarer's International Union of Canada v. Upper Lakes Shipping Limited, (1964) B.R. 737.

Shane v. Lupovich, (1942) B.R. 523.

The Foundation Company of Canada Ltd. and International Fibre Board Ltd. v. The Building and Construction Trades Council of Hull \& District and other, (1961) C.S. 22.

Thomson Electrical Works Ltd. v. McGraw et al., (1975) 11 N.B.R. (2d) 427.

Tricot Somerset Inc. v. Le Syndicat Catholique du Tricot Somerset Inc., (1954) B.R. 470.

Union Nationale des Employés de Vickers v. Canadian Vickers Limited, (1958) B.R. 470.

United Steelworkers of America v. Gaspé Copper Mines Ltd., (1967) B.R. 487.

Vapor Heating $v$. United Steel Workers of America, et al., Unreported Judgment C.S. Montreal 709,636 rendered 19 April, 1966.

Vulcan Iron Works v. Winnipeg Lodge, (1911) 21 Man. L.R. 473.

Ward Lock v. O.P.A.S., (1906) 22 T.L.R. 327 (C.A.).

Wasserman v. Sopman, (1942) 3 D.L.R. 696.

Williams v. Aristocratic Restaurants Ltd., (1951) S.C.R. 762.

Windsor Shoe and Slipper Co. v. Union des Ouvriers de la Chaussine, local 500, (1954) B.R. 266.

Authors Judicially Noted:

BEAUDOIN, Jean-Louis; La Responsabilité civile délictuelle; Montréal: Les Presses de l'Université de Montréal, 1973.

BLACK, Henry: Black's Law Dictionary: St. Paul: West Publishing Co., 1968.

CARROTHERS, A.W.R., The Labour Injunction in British Columbia; Toronto: C.C.H. Canadian Limited, 1956.

CONFÉDÉRATION DES SYNDICATS NATIONAUX, «Pour l'abolition de l'injonction dans les conflits de travail», Montréal le 8 mars, Réimpression et nouvelle présentation - Nov. 1960.

COVAL, S. et al, «The Supreme Court and a New Jurisprudence for Canada», (1975) 53 $\mathrm{R}$ du B Can. 819.

FINKELMAN, Jacob, «The Law of Picketing in Canada»; (1931) 2 Toronto L.J. 67.

GAGNON, R. et al.; «Droit du Travail en vigueur au Québec»; Québec: La Presse de l'Université Laval, 1971.

HEENAN, Roy, "Strikes, Picketing and Injunctions in Quebec»; (1967) 13 McGill L.J. 367.

LASKIN, Bora, «The Labour Injunction in Canada»; (1937) 15 Can. B. Rev. 270. 